UDC 167.7:168.3

DOI https://doi.org/10.24195/sk1561-1264/2020-1-19

\begin{abstract}
Stezhko Zoya Vasylivna
Candidate of Philosophical Sciences, Associate Professor, Associate Professor at the Department of Social Sciences, Informational and Archival Affairs Central Ukrainian National Technical University 8, Universytetskyi ave., Kropyvnytskyi, Ukraine

Kharchenko Julia Volodymyrivna

Doctor of Philosophical Sciences, Associate Professor, Head of the Department of Philosophy, Political Science and Foreign Affairs Volodymyr Vynnychenko Central Ukrainian State Pedagogical University 1, Shevchenka str., Kropyvnytskyi, Ukraine

Shalimova Nataliia Stanislavivna

Doctor of Economics, Professor,

Dean of the Accounting and Finance Faculty, Professor at the Department of Audit, Accounting and Taxation Central Ukrainian National Technical University 8, Universytetskyi ave., Kropyvnytskyi, Ukraine
\end{abstract}

\title{
GEORG HEGEL'S “PHILOSOPHY OF SCIENCE" AS A METHODOLOGY FOR RESEARCHING SOCIO-HISTORICAL PROCESSES
}

This article analyses the philosophical concept of G. Hegel as a system of evidentiary knowledge based on a reasonable comprehension of reality, and as a system of categories with methodological possibilities in explaining and predicting socio-historical processes. The relevance of the topic is determined by the need to find a solution to the problem of patterns in socio-historical processes. The purpose of article is to explore the methodological possibilities of Hegel's philosophy in explaining and predicting socio-historical processes - in the context of rational epistemology. Study methods: the method of ascent from abstract to concrete, the method of the unity of historical and logical, and so the general scientific methods - analysis and synthesis, induction and deduction, comparative analysis, abstracting. Results. The deep internal logic of interconversions of the philosophical categories of Hegel's system has been presented. The movement of abstraction follows the context of Hegel's methodology from the initial rationalization of the diversity of historical events to the comprehension of their integrity in historical and philosophical laws. The objective and subjective factors that determine the difficulties of this process have been distinguished and analyzed. The specifics of Hegel's understanding of freedom and historical necessity and their influence on the formation of general laws of history have been considered. The place and role of irrational and subjective factors in the "canvases» of the knowledge of the laws of social development have been determined. The example of the position on the dialectic of quantitative and qualitative changes illustrates the methodological possibilities of Hegel's philosophy in the field of history.

Key words: methodology, epistemology, rationality, history, science, law, freedom, postmodernism.

Introduction. It would not be a great exaggeration to say that the main direction of people thinking in all times is historical discourse. It means everyday life (as primary history), with the main question being how to optimize it, how to make it more comfortable. The superficial simplicity of phenomena and the over-complexity of essence interweave miraculously in this discourse. It is understandable that innumerable simple scripts (e.g. power or mysticism) and deep theoretical developments in all ages accompany humanity, including whether history has a sacred meaning, whether it is subject to scientific laws and whether it is correct to speak of the regularity of social progress. Research and historical experience show that systemic progress in all spheres of social life is impossible and that scientific searches for some laws of history whose basis could make it possible to «construct» the 
optimal future give, in fact, no stable results, and neither do religious-mystical quests. Moreover, the idea is commonplace today that the mind cannot show any regularity (well-known are Bertrand Russell's words that history can be called science only with the help of silences and falsifications) in the continuous variability of ordinary historical events. At the same time, we have many facts opposite to this, with instances of successful modeling and forecasting of historical processes based on historical patterns. All of the above determines our interest in this discourse and in rethinking the theoretical and methodological approaches to its solution. Using Hegel's philosophical concepts in the educational aspects of methodology for a specific science - history - can help in discussing the problems of the discipline of "Philosophy of Science", which postgraduates study at Ukrainian universities. Such considerations make our topic here relevant.

R. Aron, K. Marx, K. Popper, A. Toynbee, J. Habermas, O. Spengler, I. Janzhul and others studied the basis for the unity of history, its meaning or general regularities at different times. There aren't many philosophers in modern Ukrainian philosophy (V. Andrushchenko, M. Mikhalchenko, A. Khalapsis) analyze separately the topic of the history laws and make the reasoned conclusions both negative and positive. Mostly one's own position about the existence of general laws of history is not argued but is given superficially. Such positions can be criticized, but it should be borne in mind that "heroic attempts over the past three millennia to identify the laws of history have failed" [1, p. 9].

Generally we see that today philosophers take an opposite positions about the very existence of the history laws. A. Ivin declares: "It is important to note that the humanities do not discover the laws of science. There are no laws of history, laws of linquistics and so on" [2, p. 257]. Graeme Snooks declares an opposite: "It is a common error to believe that a "free" society can only exist if there are no laws of history. In fact the reverse is true. Human society, either free or unfree, could not exist in a world devoid of laws of history" [1, p. 6]. But meanwhile he rises a question: "If history has laws why haven't they been discovered?" [1, p. 10]. Following situation, we think, could be characterized with one word: "Confusition - before task greatness. And still " $<\ldots$..> every generation demonstrates some events to be regular and predictable, which the preceding generation had declared to be irregular and unpredictable: so that the marked tendency of advancing civilization is to strengthen our belief in the universality of order, of method, and of law" [3, p. 106; 4].

For sure, it is impossible to solve such points in the frameworks of this paper but to support an idea that "until more accurate conceptions are acquired, no secure advance can be made toward discerning the true order of social changes" [5, p. 204], we cannot as well because our position is that every scientific and philosophical contribution to the study is useful.

Purpose and objectives. Therefore, the purpose of our article is to explore the methodological possibilities of Hegel's philosophy in explaining and predicting socio-historical processes. The process of achieving this goal involves solving such problems: to determine (in the context of rational epistemology) in practice points for increasing the effectiveness of the methodological requirements of the concept of Hegel.

Methodology. The methodological basis of the research is the well-known basic philosophical theories and principles. To achieve the objective the complex of general scientific methods has been used: analysis, synthesis, induction, deduction, abstraction, systematization, compilation, review, comparison, the method of ascent from abstract to concrete, the method of the unity of historical and logical, and so the general scientific methods - analysis and synthesis, induction and deduction, comparative analysis, abstracting.

Results. Hegel on the path of science and the formation of its laws

There is much world philosophical literature devoted to comprehending Hegel's system. His works have been republished in several countries [6;7, p. 477; 8, p. 233], dissertations have been defended (Ukrainian creative work is D. Chyzhevsky's dissertation) and many monographs [9, p. 267] and many papers $[10$, p. 223] have been published.

However, that is not to say that today the effectiveness of Hegel's concepts as methodology is equal to the completeness of its content. It is possible to note the research papers that analyze Hegel's attitudes toward religion, morals and art, but they are often used according to methods of selective 
and partial reading. This method is good only in cases where the partial problem is researched through the prism of a general concept. The difficulty with understanding complex texts and their practical non-verifiability is comprehensibly met by subjective reading. Today, the difficulty does not absolve philosophers of the responsibility for the inordinate influence on everyday life of "anti-Hegelian" postmodern concepts. It is undeniable that Hegel's vision of philosophical principles and categories could open not only deep connections to the past, but also the internal logic of a variety of modern social and historical processes.

Next, we give a generalized picture of Hegel's philosophical system what is represented within the framework of rational epistemology. This includes categories of generality, laws, necessity, and randomness, freedom, that which is permeated with the principles of dialectics (interconnection, interaction and development), rationality, objectivity, and determinism. These create the primary spiritual "skeleton" of the highest level of abstraction, though a variety of everyday life has to fit it intentionally. This is probably a reason for a widespread opinion that the philosophical concept of Hegel is the fully deductive construction: "The metaphysical historicists $\langle\ldots\rangle$ focused solely on metaphysical constructs of the mind that have no application to the reality of the everyday world. These great thinkers include <..> Plato, Hegel, Marx, Spencer, Spengler, and Toynbee" [1, p. 3]. However, mr. Hegel says that "philosophy owes its development to experience" $[11$, p. $670 ; 12$, p. 64]. Therefore it follows that the hierarchy of the structure of the categorical apparatus of Hegel's philosophy has for the ground a real earthly life. At the heart of the hierarchy of the structure of the categorical apparatus of Hegel's philosophy, at the heart of its essence is a certain private act with its various contents, where "the general quality of the action in general, its vivid content is reduced to a primitive form of generalization" $[11$, p. $233 ; 12$, p. 87]. The freedom comes out from the spirituality of a personality, as "Me - it is only that what is related to my freedom <..." [11, p. 233; 12, p. 84-85]. Hegel's principle of rationality (with its undeniable domination) is combined with a certain recognition of the irrational, or "mysticism", that "is definitely somewhat mysterious" in everyday life [11, p. 670; 12, p. 266]. With these and similar statements, we want to support the idea that Hegel's system of philosophical categories is not a logical construction separated from reality, but rather an all-round, deep manifestation of rational being that has great methodological significance. With this it differs from some modern and fully deductive «constructions» of the laws of history: "The discussion of endless minute historical details must be reserved until the law of social changes has been deduced from more general phenomena, and is ready for inductive verification" [5, p. 198].

Is the beginning for the moving of abstraction in the process of the formation of the history laws "cognition of the all-round in the sea of empirical singularities, studying the necessity, the law in the visible disorder of infinite number of events" [11, p. 670; 12, p. 53]. That is, since "what consequences are accidental and what consequences are necessary, that lefts unspecified" [11, p. 233; 12, p. 85], it is worth turning to the sources or, as historians say, to the "factual base for such studies" [13]. After, the abstraction movement leads to the formation of empirical sciences - different social projects in the sphere of economics, law, ethics and politics. They have their own laws, but does history have general laws at this stage? History does not have it. However, the fact that the very history, no doubt, is as "the general background", a single reason for the formation and functioning of the laws of some spheres of society. The reason is pointed out by Hegel: laws as "lessons of history" do not go beyond the limits of finite relations, and "finality $<\ldots>$ has constant boundaries and limitations" [11, p. 233; 12, p. 84]. In other words, these are the laws of brain, the methodological capabilities of which are limited by common sense. But, according to Hegel, "Empirical sciences, on the one hand, do not stop on the perception of single phenomena, but, they moving to philosophy, they handle a material by thought: finding out a general definition, genus and laws, they prepare using this method a content of special up to the possibility of inserting it to philosophy" [11, p. 670; 12, p. 64]. We think that this Hegel's position has a detailed methodological indication - the general laws of history could be formed only in philosophical discourse.

Short conclusions can be summed up. Does history have such laws? It does. There are as followers: 
1. Empirical laws, which are formed as the results of initial rationalizations of day-to-day events carrying out a method of taking randomness out from the coincidences of the particular, that is, by the standardization process of facts and abstraction.

2. The statistical laws that regulate mass phenomena in different spheres of society, because they are laws of middle sizes. These empirical and statistical laws do form history as certain integrity with its own categorical apparatus that performs methodological functions in relation to its own spheres [14].

3. Laws-tendencies, which also have probabilistic and statistical content; they are universal, "visible" only in large systems, and work for a long time. They penetrate into the essence of the object under study, clarifying the methodological requirements of empirical laws and methodological requirements - history as a science.

An example would be the law on the priority of public life in relation to public consciousness. The follower of Hegel, materialist and rationalist K. Marx, formulated this law. Some schools call it the thesis or the principle. However, that could be called the historic and philosophical integral law in accordance with its practical influence to the social level. A. Maslow concretized this law at the individual and psychological level; it is widely used in practice.

\section{Analysis of the effectiveness of methodological guidelines in the study of history problems}

However, the effectiveness of these lessons of history is quite low, as social practice, more than the others are, does not follow the philosophical guidelines. This situation involves both objective and subjective factors. With regard to objective factors, we must address the specifics, both as a social practice and in terms of a philosophical understanding of it. We next consider this question in detail.

With regard to social practice, Hegel, analyzing not a form but a content of the movement of abstraction, focuses on a certain step away from objectivity in the content of definitions in the initial rationalization of social and historical processes. In particular, the bias of the scientist contributes to it (e.g. when he transmits the spirit of time, this last one is unquestioningly, according to Hegel, "the spirit of the scientist") and to the probability of breaking the principle of historicity (e.g. if a scientist has, as an object for study, facts in the form of diverse sources, such as documents of a past time, but he assesses them from the point of view of the present day). Moreover, if we add an external variety of manifestations of facts of the history as a research object, it becomes clear that some uncertainty and ambiguous conclusions of rational analysis are objective, such that full rationalization of events on the specific level proves impossible and can never be fully proven.

However, the impossibility of full rationalization of social and historical processes at the general stage is obvious and related to yet another problem of philosophical comprehension of the social practice: while explaining the content of real events is no longer a dominant concern, what has become dominant is understanding their essence. This is controversial and ambiguous, as it concerns the difficulties of the philosophical analysis as well as our understanding of it. We are going to demonstrate this statement using the dialectics of categories for freedom and necessity (" $<\ldots>$ truth and freedom need each other - neither can go it alone" [15]. Freedom for humanity is, for sure, a point of departure, but humanity is able to be absolutely free only at the moment of intention, subjectively. In fact, "laws say only definitions of content for objective freedom definition" [11, p. 738, 602], so freedom becomes more objective and relative because it is limited by external determination and necessity. That is, the movement of abstraction from initial history to philosophy turns upside-down the meaning of the point of departure at the end. In addition, if the cognition of history is aimed at realizing rational integrity, it has to see free actions as necessary and determined, which is an obvious contradiction.

Since we have already analyzed the contradictory and ambiguous nature of the category of freedom [16, p. 65-78], we add that historical necessity is also contradictory and ambiguous:

- if results of events are necessarily stemming from its motives, an inevitability of a complex binding of these motives causes the randomness; historic necessity in this aspect is equal with the randomness;

- if a need is laid down in the laws that manage events, then these laws determine the necessary condition of social being - not a chronology of history - and a specific character of historicity gets lost in the necessity; 
- if the need is the need of methods that realize laws of social being, then even evil might be necessary, and we fall into contradiction again, since the requirements of historical need are not rules of morality.

As we see, all characteristics of historical needs are from reality, but they do not pivot on unambiguity as a dominant line in the "disjointed visibility of events". If we are talking about the realization of freedom in practice and the need as an occurrence of categories in relation to simple causality at one-time and specific stages, a problem becomes obvious.

With regard to subjective factors, we see some underestimation of the possibilities of argumentation through the philosophical analysis of words, which significantly reduces the effectiveness of research, when applying categories of philosophy can be quite effective even in the analysis of specific areas of social reality, such as economics [17, p. 84-95]. An example is the practice of disambiguation in the use of the word "freedom"; this practice we consider inadmissible in "pragmatic history" (Hegel). But the meaning of freedom is understood in a wide range of values - from absolute to relative, from subjective to objective; as a "sweet" emotional word, as a concept and as a category. At the stage of primary rationalization, freedom is based "on conviction", on the stage of universalism - on "reliability which based on knowledge of necessity <...>" (Hegel).

Hegel keeps in mind the inevitably (i.e. in terms of permissibility) emotional and strong-willed component of the concept of freedom and the absolutizing of it; thus, it is thought that at the general stage, philosophy has changed and can change the concept of freedom to reliably include categorical content while limiting, by rational frames, the emotional aspects. This is a powerful methodological guide, an optimal philosophical compass. However, V. Khmil underlines correctly that "nowadays politological analytics dominates over philosophic explanation of complex democratic processes making inner basis of social human being more obscure instead of clear identification of human values and future global prospects" [18, p. 47]. This situation significantly reduces the possibility of a true understanding of the events in their deep causality. As outcomes, the constituent concepts of freedom manifest themselves with different content in practice (most often as subjective principles), and ignoring this moment of manifestation is one of the major causes of popular upheaval.

Another subjective factor that reduces the effectiveness of methodological guides of philosophy today is an attitude of philosophers to philosophy. What do we mean?

The "trick of mind" is a cause for taking the first position in subjectivist philosophy, as Hegel says. The possibilities of philosophy as a mental game are extremely broad, from a neglect of the basic philosophical principles that are developed in the millennia's process of developing elitist philosophical thought, to a denying of philosophy itself as a world outlook and methodology. Nevertheless, the formation of postmodernism philosophy went directly through the negation of Hegel's philosophy. In the theoretical aspect of the analysis of social practice, we consistently observe the destruction of relationship, and then the complete separation of principles from the categories saving the ontological content of categories. The priority of values is established through a partial replacement of the objective ontological content of categories with values. In the future, this may lead to the complete removal of the objective ontological content of the categories and to its replacement with simulacra. Simulacra are connected by the principles of, for example, indeterminism, subjectivity, irrationality and post-truth. Following Hegel's logic, an illusory picture of the world is practically offered. This is a big problem today, because the "scenario" described in Hegel's philosophical concept is actually realized indeed: if we are to abstract from mind its objective aspects, then there will, in fact, be nothing to control mental activity. It will instead be a thought that changes arbitrarily according to our interests and will.

G. Hegel's philosophy as a roadmap for solving problems of social and historical processes

A way that points to resolving the problems of both past and present day social and political processes can be found with Hegel: "Inevitably comes the time when thought and notion declare its right". A harbinger of this time is not the fact of the radical distinction between "social science and political superstructure" and reality, but the fact that this distinction is concerned with an increasing number of people. Hegel's dialectic of quantitative and qualitative changes explains this as follows: 
the negativism of quantitative accumulation becomes critical to reaching a deadline for the measure behind which the qualitative change of the social paradigm inevitably becomes directed to the "objective-substantive aspects" of the mind.

Applying this rather abstract position of Hegel in the sphere of pragmatic history, we say that this transition cannot be total, since the sensory (somewhat irrational) experience of the average person is not wiped out, and thus this total transition is not possible. However, it is possible to balance and stabilize it within the framework of a general rational system, since the mind can take into account the emotional and irrational moments, i.e. "mysticism". This is the logic of Hegel's reflection.

By carefully and respectfully understanding the spirit and logic of Hegel's philosophical heritage, it is possible to reach a solution of the methodological problems of social and historical practice, to adjust intentions and values of the social subject to a stream of civilized coexistence. For example, the inability to fully rationalize historical events (noticed by Hegel at the stages of knowing the special and the general, thus introducing ambiguity and contradiction into the laws) does not necessarily testify to the "unscientific" nature of history, as its opponents claim. Its position is caused by a desire of common sense to be guided by "laws-recipes" or, by analogy, with the unambiguity of the dynamic laws of the natural sciences. However, the analogy is incomplete: modern scientific knowledge of quantum mechanics has shown that there are probably statistical (and not dynamic) regularities in the microcosm. This is why it is right to recognize the laws of history as a science, placing them within the permissible framework of ambiguity.

Hegel, using the dialectic of the categories, has repeatedly noted that although historical events are separate, i.e. distinct from one another, they are also common and internal, and, through their connections, are one. It constantly "removes" the past, making the events modern, and stretches the "lead thread" to a future event, which ensures its continuity as regularity.

Only a radical attitude change to history will optimize its effectiveness in practice. Moreover, extremely important is a constant and respectful cooperation with philosophy, because other sciences (Hegel argues) will not be able to master the truth without calling on philosophy. Therefore, we must be aware that every coming historical period will reflect philosophical conceptualization as a methodology of scientific knowledge.

Conclusions. The methodological possibilities of Hegel's philosophy study allows us to draw the following conclusions:

1. Hegel's system of philosophical categories is not an abstract logical construction, but a comprehensive, deep manifestation of the rationality of being.

2. Hegel traces the logic of cognition of social and historical processes in the movement of abstraction from primary scientific rationalizations up to the formation of the conceptual apparatus of history and then to the formation of the system of categories of social philosophy.

3. At these cognition etaps are the step by step forming first the stable "regularities", cause-effect relationships of common sense, then - the probabilistic statistical laws of individual spheres of social life, primarily the economy; the general laws of history are able to be formed only in the philosophical discourse.

4. A significant role for the process systematization of knowledge belongs to the principles of rational philosophy, as well as to categories - this is shown using an example of the categories "freedom-necessity".

5. Low efficiency of application of laws, principles and categories of philosophy in explaining and foreseeing social processes has objective and subjective reasons. Objective reasons include the impossibility of complete rationalization of social processes, the contradictory and ambiguous nature of historical necessity and freedom; subjective factors include 1) low assessment by politicians of philosophical argumentation in determining the strategy of the state; 2) partial replacement of the objective ontological content of categories with values - first of all, simulacra of postmodernism.

6. The solution of methodological problems of modern socio-historical practice should be seen in the following: recognition of the impossibility of forming unambiguous "recipe laws" and recognition of the impossibility of full rationalization of historical events naturally lead to the conclusion that 
there are laws of history within the acceptable framework of polysemy. Indeed, although individual historical events differ from each other, their internal essential connections are the same. It is they who stretch a single "guiding thread" from the past through the present to future events - and turn their continuity into a pattern.

\section{Bibliography}

1. Snooks, Gr. The Laws of history. London ; New York : Routledge, 1998. 293 p.

2. Ивин А. Социальная эпистемология: Человеческое познание в социальном измерении : монография. Москва ; Берлин : Директ-Медиа, 2017. 570 с.

3. Berlin I. The Concept of Scientific History. History and Theory. 1960. Vol. 1. № 1. P. 103142. URL: http://berlin.wolf.ox.ac.uk/published_works/cc/scihist.pdf (дата звернення: 10.08.2020).

4. Murphy G. Sir Isaiah Berlin on the Concept of Scientific History: A Comment. History and Theory. 1965. Vol. 4. № 2. P. 234-243. URL: https://www.jstor.org/stable/2504153 (дата звернення: 15.08.2020).

5. Fiske J. Reviewed Works: A History of the Intellectual Development of Europe by John William Draper; Ancient Law; Its Connection with the Early History of Society, and Its Relation to Modern Ideas by Henry Sumner Maine. The North American Review. 1869. Vol. 109. № 224. P. 197-230. URL: https://www.jstor.org/stable/25109488?seq=1\#metadata_info_tab_contents (дата звернення: 18.08.2020).

6. Hegel G. Lectures on the history of philosophy [Vorlesungen über die Geschichte der Philosophie]. 1892. 856 p. URL: http://archiv-swv.de/pdf-bank/Hegel.G.W.F.Vorlesungen.ueber.die.Geschichte.der.Philosophie.I.pdf (дата звернення: 18.08.2020).

7. Hegel G. The Philosophy of History. Prefaces by Charles Hegel and the Translator, J. Sibree, M.A. Ontario : Kitchener, 2001. 450 p.

8. Hegel G. Grundlinien der Philosophie Rechts [Principles of Philosophy Right.] Berliner Ausgabe, 2013. 240 p. URL: http://www.zeno.org/Lesesaal/N/9781484031919?page=0 (дата звернення: 18.08.2020).

9. Stähler T. Die Unruhe Des Anfangs: Hegel und Husserl über den Weg in die Phänomenologie [The unrest of the beginning: Hegel and Husserl on the way into phenomenology]. Kluwer Academic Publishers, 2003. 275 p.

10. Pippin R. Kunst als Philosophie. Hegel und die moderne Bildkunst [Art as philosophy. Hegel and the modern visual art]. Berlin : Suhrkamp, 2013. 199 p.

11. Hegel G. Enzyklopädie der philosophischen Wissenschaften im Grundrisse in IV Bänden. Band 1 [Encyclopedia of philosophical sciences in the floor plan in IV volumes. Vol. 1]. 1830. $670 \mathrm{p}$. URL: http://bookre.org/reader?file=1554944 (дата звернення: 18.08.2020).

12. Hegel G. Enzyklopädie der philosophischen Wissenschaften im Grundrisse in IV Bänden. Band 3 [Encyclopedia of philosophical sciences in the floor plan in IV volumes. Vol. 3]. 1830. 738 p. URL: http://www.archiv-swv.de/pdf-bank/Hegel.G.W.F.Enzyklopaedie.der.philosophischen.Wissenschaften.III.pdf (дата звернення 18.08.2020).

13. Орлик В., Орлик С. Теоретико-методологічні та джерелознавчі проблеми економічної історії України. Універсум історії та археологіï. 2020. Вип. 2 (27). № 2. С. 5-25.

14. Orlik V. W sprawie Metodologii badań numizmatycznych. Recenzja książki A.L. Ponomarev, Èvolûciâ denežnyh sistem Pričernomor'â i balkan XIII-XV vv. Moskva : Izdatel'stvo moskovskogo universiteta, 2011. 672 s. ISBN 978-5-211-06307-5. Wiadomości Numizmatyczne. 2014. R. LVIII. Z. 1-2 (197-198). S. 259-263.

15. Lynch M. Truth and Freedom. The European Legacy. 2014. Vol. 19. № 2. P. 23-33. DOI: $10.1080 / 10848770.2014 .876198$.

16. Стежко 3.В., Стежко Ю.Г. Суперечливість свободи та парадокси відповідальності : антропологічний аналіз. Anthropological Measurements of Philosophical Research. 2018. № 13. P. 65-78. URL: http://dx.doi.org/10.15802/ampr.v0i13.131937 (дата звернення: 15.08.2020).

17. Shalimova N., Stezhko, Z. Qualitative Characteristics of the Auditor's Report. Research Journal of Finance and Accounting. 2016. Vol. 7. № 4. P. 84-95.

18. Khmil V. Ambiguous Janus of Modern Democracy. Anthropological Measurements of Philosophical Research. 2016. № 9. P. 47-54. URL: http://dx.doi.org/10.15802/ampr2016/72228 (дата звернення: 15.08.2020). 


\section{References}

1. Snooks, Graeme Donald (1998). The Laws of history. London and New York: Routledge.

2. Ivin A.A. (2017). Social epistemology. Human cognition in the social dimension: monograph. M.; Berlin: Direct-Media [in Russian].

3. Berlin, Isaiah (1960). The Concept of Scientific History. History and Theory, Vol. 1, № 1, 103-142. http://berlin.wolf.ox.ac.uk/published_works/cc/scihist.pdf; https://www.jstor.org/stable/2504255? origin $=$ crossref.

4. Murphy, G.G.S. (1965). Sir Isaiah Berlin on the Concept of Scientific History: A Comment. History and Theory, Vol. 4, № 2, 234-243. https://www.jstor.org/stable/2504153

5. Fiske, John (1869). Reviewed Works: A History of the Intellectual Development of Europe by John William Draper; Ancient Law; Its Connection with the Early History of Society, and Its Relation to Modern Ideas by Henry Sumner Maine. The North American Review, Vol. 109, № 224 (Jul., 1869), 197-230. https://www.jstor.org/stable/25109488?seq=1\#metadata_info_tab_contents.

6. Hegel, G. (1892). Lectures on the history of philosophy. [Vorlesungen über die Geschichte der Philosophie]. http://archiv-swv.de/pdf-bank/Hegel.G.W.F.Vorlesungen.ueber.die.Geschichte.der. Philosophie.I.pdf [in Deutsche].

7. Hegel, G. (2001). The Philosophy of History. Prefaces by Charles Hegel and the Translator, J. Sibree, M.A. Ontario: Kitchener.

8. Hegel, G. (2013). Grundlinien der Philosophie Rechts. [Principles of Philosophy Right.] Berliner Ausgabe. http://www.zeno.org/Lesesaal/N/9781484031919?page=0 [in Deutsche].

9. Stähler, T. (2003). Die Unruhe Des Anfangs: Hegel und Husserl über den Weg in die Phänomenologie. [The unrest of the beginning: Hegel and Husserl on the way into phenomenology]. Dordrecht, Boston, London. Kluwer Academic Publishers. https://zfphl.de/index.php/zfphl/article/ view/17/29 [in Deutsche].

10. Pippin, R. (2013). Kunst als Philosophie. Hegel und die moderne Bildkunst. [Art as philosophy. Hegel and the modern visual art]. Berlin: Suhrkamp. https://zfphl.de/index.php/zfphl/article/ view/17/29 [in Deutsche].

11. Hegel, G. (1830a). Enzyklopädie der philosophischen Wissenschaften im Grundrisse in IV Bänden. Band 1. [Encyclopedia of philosophical sciences in the floor plan in IV volumes. Volume 1]. http://bookre.org/reader?file=1554944 [in Deutsche].

12. Hegel, G. (1830b). Enzyklopädie der philosophischen Wissenschaften im Grundrisse in IV Bänden. Band 3. [Encyclopedia of philosophical sciences in the floor plan in IV volumes. Volume 3]. http://www.archiv-swv.de/pdf-bank/Hegel.G.W.F.Enzyklopaedie.der.philosophischen. Wissenschaften.III.pdf [in Deutsche].

13. Orlyk, V.M., \& Orlyk S.V. (2019). Theoretical and methodological and scientific problems of the economic history of Ukraine. Universum of History and Archeology, Vol. 2 (27), Iss. 2, 5-25. http://dx.doi.org/10.15421/2619022702.

14. Orlyk, V. (2014). On the Methodology of numismatic research. Numismatic News, Vol. 1-2 (197-198), 259-263 [in Poland].

15. Lynch, Michael P. (2014). Truth and Freedom. The European Legacy, Vol. 19, № 2, 23-33. http://dx.doi.org/10.1080/10848770.2014.876198

16. Stezhko, Z. \& Stezhko, Ju. (2018). Contradiction of freedom and paradoxes of responsibility (anthropological analysis). Antropologhichni vymiry filosofsjkykh doslidzhenj, 13, 65-78. http://dx.doi.org/10.15802/ampr.v0i13.131937 [In Ukrainian].

17. Shalimova, N. \& Stezhko, Z. (2016). Qualitative Characteristics of the Auditor's Report. Research Journal of Finance and Accounting, vol. 7, № 4, 84-95.

18. Khmil, V. (2016). Ambiguous Janus of Modern Democracy. Antropologhichni vymiry filosofsjkykh doslidzhenj, 9, 47-54. http://dx.doi.org/10.15802/ampr2016/72228. 
Стежко Зоя Василівна

кандидат філософських наук, доцент, доцент кафедри історії, археології, інформаційної та архівної справи Центральноукраїнського національного технічного університету пр. Університетський 8, Кропивницький, Україна

Харченко Юлія Володимирівна

доктор філософських наук, доцент, завідувач кафедри філософії, політології та міжнародних відносин Центральноукраїнського державного педагогічного університету імені Володимира Винниченка вул. Шевченка 1, Кропивницький, Україна

Шалімова Наталія Станіславівна доктор економічних наук, професор, декан факультету обліку та фінансів,

професор кафедри аудиту, обліку та оподаткування Центральноукраїнського національного технічного університету пр. Університетський 8, Кропивницький, Україна

\section{«ФІЛОСОФІЯ НАУКИ» ГЕОРГА ГЕГЕЛЯ ЯК МЕТОДОЛОГІЯ ДОСЛІДЖЕНЬ СОЦІАЛЬНО-ІСТОРИЧНИХ ПРОЦЕСІВ}

У статті аналізується філософська концепиія Г. Гегеля як система доказових знань, які базуються на раціональному осмисленні дійсності, та як система приниипів $і$ категорій із методологічними можливостями в області філософії науки, зокрема історії. Актуальність теми визначається необхідністю пошуку рішення тисячолітньої проблеми закономірностей у соціально-історичних процесах та надання історії статусу науки. Метою статті є внесення посильного вкладу у визначення методологічних можливостей філософської концепції Г. Гегеля в поясненні, передбаченні та прогнозуванні соиіально-історичних процесів - $у$ контексті раціональної епістемології. Методи та результати дослідження. Методологією є приниини, категорії та методи раџіональної філософії-сходження від абстрактного до конкретного, єдності історичного та логічного, а також загальнонаукові методи - аналіз та синтез, індукція та дедукція, порівняльний аналіз, узагальнення, абстрагування. Представлено глибинну внутрішню логіку взаємопереходів філософських категорій конщепиії Г. Гегеля, яка визначає рух абстракиії від початкової раціоналізації розмаїття конкретних історичних подій до розуміння їхньої глибинної иілісності та каузальності. Обгрунтована можливість формування загальних законів історії, проте: 1) лише в історико-фрілософському дискурсі; 2) лиме у прийнятних рамках багатозначності (із визнанням приниипової неможливості повної раціоналізації історичних подій). Проаналізовано причини, щчо знижують практичну ефективність імплементації методологічних вимог. Робиться висновок про необхідність переорієнтації державної політики на повагу до філософської методології. Розглянуто специфіку розуміння Г. Гегелем свободи й історичної необхідності та їхній вплив на формування загальних законів історії. Визначено місие та роль ірраціональних суб'єктивних чинників постмодернізму в «канві» пізнання законів суспільного розвитку. Проілюстровано ефективність методологічних вимог філософії Г. Гегеля в галузі історії на прикладі діалектики кількісних та якісних змін.

Ключові слова: методологія, епістемологія, рачіональність, історія, наука, закон, свобода, постмодернізм. 